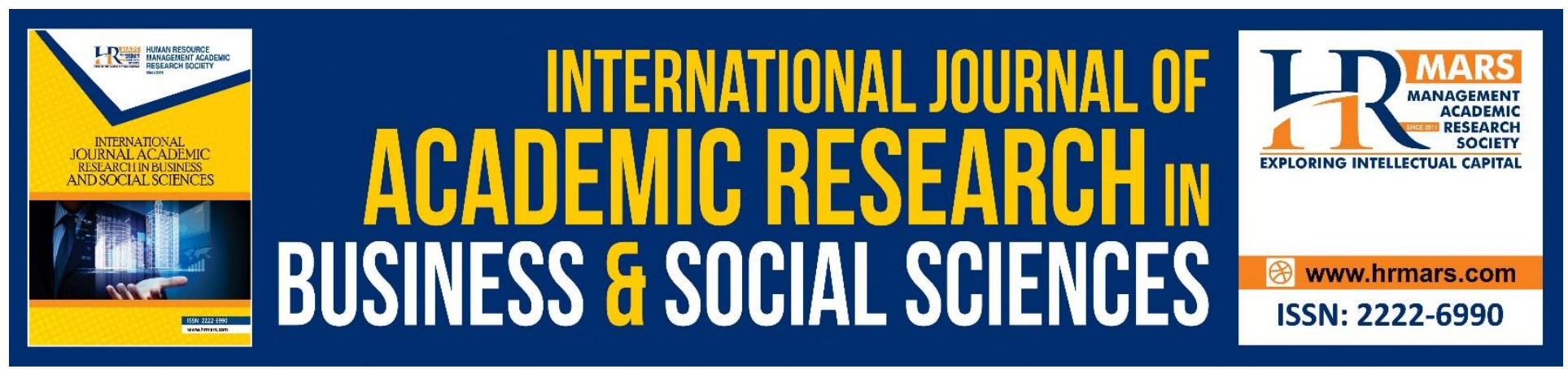

\title{
Exploring the Development of Human Capital for Desapreneur Development in Malaysia
}

\author{
Nurul Nadiah Ahmad, Wan Mohammad Taufik Wan Abdullah \& Nurul Nazlia \\ Jamil
}

To Link this Article: http://dx.doi.org/10.6007/IJARBSS/v10-i10/7999

DOI:10.6007/IJARBSS/v10-i10/7999

Received: 06 August 2020, Revised: 27 August 2020, Accepted: 12 September 2020

Published Online: 28 October 2020

In-Text Citation: (Ahmad, Abdullah, \& Jamil, 2020)

To Cite this Article: Ahmad, N. N., Abdullah, W. M. T. W., \& Jamil, N. N. (2020). Exploring the Development of Human Capital for Desapreneur Development in Malaysia. International Journal of Academic Research in Business and Social Sciences. 10(10), 699-705.

Copyright: (c) 2020 The Author(s)

Published by Human Resource Management Academic Research Society (www.hrmars.com)

This article is published under the Creative Commons Attribution (CC BY 4.0) license. Anyone may reproduce, distribute, translate and create derivative works of this article (for both commercial and non-commercial purposes), subject to full attribution to the original publication and authors. The full terms of this license may be seen

at: http://creativecommons.org/licences/by/4.0/legalcode

Vol. 10, No. 10, 2020, Pg. 699 - 705

http://hrmars.com/index.php/pages/detail/IJARBSS

JOURNAL HOMEPAGE

Full Terms \& Conditions of access and use can be found at http://hrmars.com/index.php/pages/detail/publication-ethics 


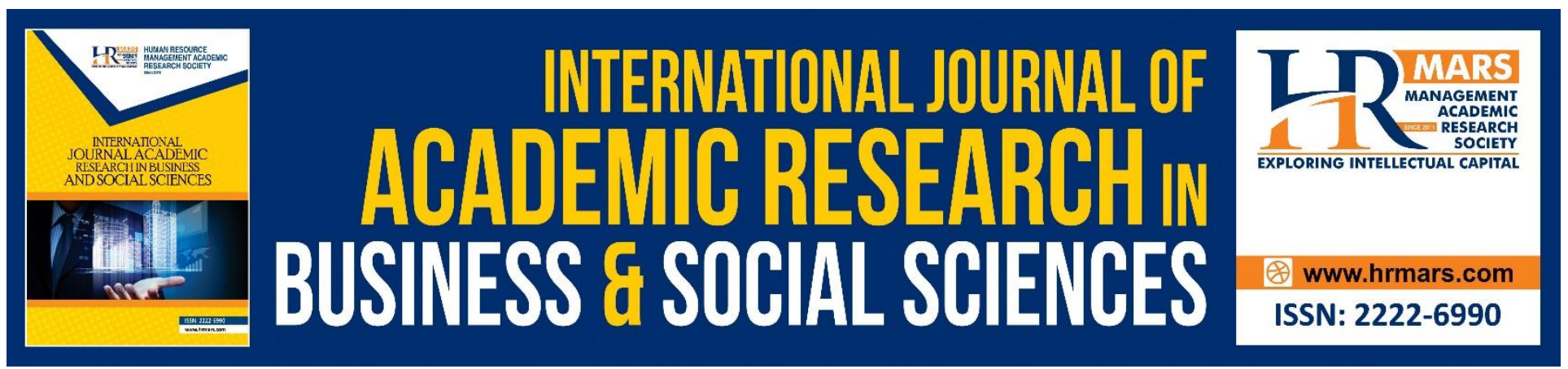

\title{
Exploring the Development of Human Capital for Desapreneur Development in Malaysia
}

\author{
Nurul Nadiah Ahmad ${ }^{1}$, Wan Mohammad Taufik Wan Abdullah ${ }^{1} \&$ \\ Nurul Nazlia Jamil ${ }^{2}$ \\ ${ }^{1}$ College of Business Management and Accounting, Universiti Tenaga Nasional, Sultan Haji Ahmad \\ Shah Campus, Malaysia, ${ }^{2}$ Faculty of Economics and Muamalat, Universiti Sains Islam Malaysia
}

(USIM), Malaysia.

\begin{abstract}
There are many initiatives taken by the capital providers to initiate more successful desapreneur. However, desapreneur is still lagging far behind with problems related to low business achievement and poor business management. Thus, this study aims to explore desapreneur development to achieve overall economic objectives. A qualitative face-to-face semi-structured interview approach will be used to select the interviewees, and they will be grouped accordingly into several categories (desapreneur, capital provider, practitioners, and policymakers). With the identification of opportunities and challenges, potentially, the outcome from the research can assist the authorities to evaluate effective strategy related to human development that will be implemented by desapreneur in rural area due to significant role of desapreneur in economic transformation and growth. This tool is expected to help the government to achieve high-income nations, aligned with the Malaysia Plan.
\end{abstract}

\section{Introduction}

In Malaysia, the involvement of Malaysian from rural areas in the entrepreneurship sector is rapidly increasing. In an effort to improve local economic growth through entrepreneurship, a new initiative was introduced by The Companies Commission of Malaysia (SSM) in the year 2018 called as desapreneur (News Strait Times, 2018). Desapreneur is synonymous with the rural entrepreneur. Desapreneur refers to the small entrepreneurs that comprise of women and youth from a rural area in Malaysia who are normally involved as sociopreneur (i.e., agriculture and marine) or as artpreneur (i.e., fabric, culinary, and craft). This initiative by SSM aims to educate and empower the desapreneur by providing business-guidance training.

There is a significant increase in human capital development to empower desapreneur, and it is given to desapreneur due to the government's target in achieving Vision 2020 (Haji \& Ghazali, 2012). In 2016, the government established Talent Corporation Malaysia (TalentCorp) as an initiative to enhance HC through the searching for competence labour (TalentCorp, 2016). In the year 2016, the 
INTERNATIONAL JOURNAL OF ACADEMIC RESEARCH IN BUSINESS AND SOCIAL SCIENCES Vol. 10, No. 10, 2020, E-ISSN: 2222-6990 @ 2020 HRMARS

human capital index by the World Economic Forum ranked Malaysia at $42^{\text {nd }}$ place from a total of 130 countries (Human Capital Report: Rankings, 2016).

Gerakan Daya Wawasan (GDW) also was introduced in 1997 with the aim of bringing out changes in paradigm among the villagers so that they will no longer rely solely on the government when they want to develop their village. However, the GDW failed due to the failure of government agencies in identifying villages suitable for the GDW project (Utusan, 2000). Besides, the rate of failure among Bumiputera entrepreneurs, specifically in the rural area is still high, and it is at an unsatisfactory level. In fact, out of 100 companies registered with the Companies Commission of Malaysia (SSM), only 18 companies were found to be successful within five years (Bernama, 2017). This issue is also supported by Marion (2011), who proved that out of five, three businesses failed within a short period of time three years. Besides, the contribution of Bumiputera entrepreneurs to the GDP is still low as it falls below $10 \%$ of total growth (Bernama, 2019).

Many factors influence the survival of a business such as people who conduct and manage the business or also known human capital (Asmawiyah, Taba, \& Hamid, 2020). Human capital is defined as the skills, knowledge, and expertise of the staff that play crucial roles to enhance business productivity. This human capital is valuable for the business as the sustainable competitive advantage's sources (Hitt et al., 2001). Asmawiyah (2018) highlighted that the human capital in the company should be managed professionally in order to create a balance between the needs of employees with the demands and capabilities of the organisation. Therefore, this research aims to identify and evaluate the human development module that is needed by desapreneur. This module will ensure that there is continuous improvement in human capital development among desapreneur, and it plays an influential role in the economic growth and standard of living of the country.

This study contributes to new literature regarding human capital development among desapreneur. There is a lack of research on the desapreneur in Malaysia, which covers the entrepreneur in a rural area. A lot of recent studies were done on a business entrepreneur in general. The combination of the current study and previous studies can help policymakers to regulate better human capital. This regulation helps policymakers to keep track of current strategies and developments to combat poverty by encouraging desapreneurs to earn their income from small-scale business activities.

\section{Literature Review}

Desapreneur or small-scale rural entrepreneurship has become one of the chief means for many countries in sustaining the country's economy. In 2017, 13 businesses were classified as a potential business for desapreneur, namely automotive, motorcycle, electrical, air conditioning, sewing and hairdressing, as well as maintenance of buildings and plumbing, photography, welding, computers, electronics and spa and beauty services (Utusan, 2017).

The number of desapreneurs has increased over the years. Accordingly, there is a lot of initial capital and financial assistance provided by the Malaysian Government to rural entrepreneurs throughout the year. For example, a total of 3,747 rural Bumiputera entrepreneurs received funding totalling RM376 million from the Rural Economic Financing Scheme (SPED) between the year 2001 and 2016. In 2017, the Rural and Regional Development Ministry set aside RM15 million to empower rural Bumiputeras (News Strait Time, 2018). In the year 2018, The Companies Commission of Malaysia (SSM) also distributed business equipment worth RM3.7 million to 1,229 BizGrant participants from five states as a platform to venture into small-and-medium-sized enterprises (SMEs) (News Strait Time, 2018). Besides, the 2019 Budget put a strong focus on capacity building for Malaysian SMEs 
INTERNATIONAL JOURNAL OF ACADEMIC RESEARCH IN BUSINESS AND SOCIAL SCIENCES Vol. 10, No. 10, 2020, E-ISSN: 2222-6990 @ 2020 HRMARS

and mid-tier companies, in particular women-owned and youth-owned businesses, to continue developing more successful Bumiputera and local entrepreneurs (News Strait Time, 2018).

\section{Human Capital}

Human Capital (HC) is one of the intellectual capital components (Frasson Vidotto, Ferenhof, Selig, \& Bastos, 2017). HC is a blend of knowledge, skills, attitudes and relationships formed in the minds, bodies, and actions of employees of a company. A company's HC is viewed as a form of valuable resources in creating a sustainable competitive advantage (Gamerschlag, 2013). According to Fontana and Macagnan (2013), efficient HC can help the company to have more business opportunities and create new ideas. The company is more confident and less vulnerable when taking any risk. Therefore, it is important for the company to have an effective HC (Felicio, Couto, \& Caiado, 2014).

Malaysian government put effort on the Human Capital Development through Strategic Reform Initiative (HCD-SRI) in the Economic Transformation Programme (ETP) in 2012. ETP was also a part of the National Transformation Programme to build Malaysia as a developed-nation by 2020 (Programme, 2016). This initiative involved many parties from the government and private entity. For example, HCD-SRI initiated workplace transformation which focuses in three areas consisting of modernising labour laws, protecting of labour in the period of economic transition, and strengthening the Small Medium Enterprises (SMEs) human resource management.

The government initiative to upskill manpower in 2012 involved 12 National Key Economic Areas (NKEA) focusing on developing skilful labour for oil, gas and energy. Actions that have been done which include a 10-day Train-the-Trainer (TTT) programme by German-based Renewables Academy (RENAC) which its purpose was to increase the current training facilities at Universiti Teknologi Mara (UiTM) and Selangor Human Resource Development Centre (Supporting Policies, 2016). ETP progress stated training programmes were developed by MSC Malaysia MyProCert Programme (MyProCert), National Talent Enhancement Programme (NTEP), Technical Education and Vocational Training (TEVT) Curriculum and Trainers' Programme to enhance the skill of the workforce in Malaysia.

Besides, SME Corporation functions to increase HC development in Malaysia by developing 44 programmes to enhance the skills of Malaysian labour. One of the efforts is Bumiputera Workshop Transformation Program (BWTP) which has increased the performance, sales, and profit of the automotive workshop businesses in Malaysia (SMECorp, 2016). SME Corporation has also developed the Youth Entrepreneurship Programme (YEP), which aims to improve the potential and current entrepreneurs on entrepreneurship, knowledge, and skill. The YEP provided youth entrepreneurs with a centre for them to build a network with the Entrepreneur Development Organisation (EDO) and Entrepreneur Financing Institution (EFI).

TalentCorp is a government agency that has been initiated by the Malaysian government to be the catalyst for great transformation through 12 NKEA (TalentCorp, 2016). This agency is the 'middleperson' between the government and companies to enhance HC. In 2015, TalentCorp was able to reduce the entry barrier for highly-skilled expatriates in the industry that faced a shortage of experts. TalentCorp also introduced tax incentives on expenses incurred by companies for internships to enhance the employability rate for graduate. TalentCorp focuses on improving the quality of graduates to be employed, engage Malaysian human resources with foreign countries, assist foreigners' skill and enhance Malaysian professionals (National Transformation Programme, 2015). 
INTERNATIONAL JOURNAL OF ACADEMIC RESEARCH IN BUSINESS AND SOCIAL SCIENCES Vol. 10, No. 10, 2020, E-ISSN: 2222-6990 @ 2020 HRMARS

\section{Theoretical Framework}

Different theories have been advanced to explain the phenomena of entrepreneurship itself. All these theories, including the "economic theory", "resource-based theory", and "opportunity-based theory" explain that an entrepreneur needs to put together a business and accepts the associated risks to do a profitable business. Specifically, the economic theory explains economic conditions and the opportunities the entrepreneur creates. However, this theory fails to recognise the dynamic, open nature of market systems, and it ignores the unique nature of the entrepreneurial activity and downplays the diverse contexts in which entrepreneurship occurs. The resource-based theory focuses on the way individuals leverage different types of resources to get entrepreneurial efforts off the ground (Pfeffer \& Salancik, 2003). Meanwhile, the opportunity-based theory explains how entrepreneurs excel at seeing and taking advantage of possibilities created by social, technological and cultural changes. In short, these theories could be used as premises to the discussion of the possible research findings.

\section{Methodology}

This study will employ a qualitative study using the interview method. A theoretical sampling will be used to select the interviewees by applying two sequential phases. In the first phase, targeted group of interviewees will be identified approximately around 100 people comprises of potential desapreneur, successful desapreneur, and practitioner, i.e., accountant and capital provider, i.e., SME Corp, SSM and AIM. Potential desapreneur will be selected from 28 poorest districts in Malaysia, as reported by the Ministry of Rural Development (Bernama, 2019). These targeted people are beneficial to the study as their insights in the policy and development on desapreneur will help to evaluate the challenges faced by the desapreneur as a whole. In the second phase, after the targeted groups were identified, the researcher will communicate with the targeted candidates to check their availability. The researcher will use the telephone and email to communicate with them and provide an offer letter explaining: (i) the objectives of the study, (ii) the purposes of the interview; (iii) information about the researcher and the university; (iv) the time required for the interview, and ( $v$ ) how confidentiality would be ensured. According to Bailey and Peck (2013), these procedures are able to increase credibility and will encourage willingness from the practitioners to participate in the study.

Face to face semi-structured interviews will be employed and the data analyses will be done with the description of the interviewees, the business to which they are established, age, working experiences, and business experience followed by an analysis of the interview the interviewees' views on relevant themes. The steps involved in the analysis of the interview data will be divided into few processes such as transcription, coding, and interpretation process. In the transcription process, the interview records will be transcribed word by word. Data from the interview transcripts will be classified and coded according to the initial themes and categories. After the manual coding completed, all of the transcripts will be uploaded into Nvivo (a computer software package for qualitative data analysis), and codes will be applied electronically to the transcripts.

\section{Conclusion}

The objective of this study is to identify and to evaluate the human development module needed by desapreneurs. This study will reveal many initiatives given by the regulators and policymakers to enhance desapreneur programme. However, there is a lack of disclosure in details on human capital 
INTERNATIONAL JOURNAL OF ACADEMIC RESEARCH IN BUSINESS AND SOCIAL SCIENCES Vol. 10, No. 10, 2020, E-ISSN: 2222-6990 @ 2020 HRMARS

development by the regulators. Therefore, the finding of this study may indicate the need for proper development of the Human Capital Development Index for desapreneur based on the expectation from all parties involved. In addition, this fundamental provides good material as guideline and references, especially to desapreneur, Malaysia government, Malaysia Productivity Corporation (MPC), entrepreneur consultants and to local and international academia. Also, it would be beneficial for future researchers as an avenue for references in such similar interest.

The outcome from the research will help desapreneur to evaluate an effective strategy to have a successful entrepreneur in the initial year. The identification of the human development weakness at the beginning will improve the weakness, problem and issues of desapreneur in which indirectly will close the income gap between urban and rural areas. In future, it will make desapreneur in Malaysia compatible with international norms, and that should smoothen cross-border investment and trade to achieve the objective of high-income nations as projected by GDP growth between $4.5 \%$ and 5.5\% per annum from 2018 to 2020 as reported in $11^{\text {th }}$ Malaysia Plan 2016-2020.

The finding from the research can bring in the necessary legal instruments and proper monitoring to ensure the programme for desapreneur will be a plan and will be developed effectively and efficiently. It will ensure that this program will re-engineer economic growth for greater prosperity through investing in competitive cities and regional economic corridors development (Economic Planning Unit Malaysia, 2015).

\section{Acknowledgement}

We are thankful to UNITEN for the Internal Research Grant (BOLD), which enabled this research to be conducted.

\section{References}

"Azmi perjelas punca GDW gagal,," Utusan. (2000). 06/12/2000, http://ww1.utusan.com.my/utusan/info.asp?y=2000\&dt=1206\&pub=utusan_malaysia \&sec=Dala m_Negeri\&pg=hn_04.htm

"Bumiputera entrepreneurs' contribution to GDP still low," Bernama. (2019). https://www.freemalaysiatoday.com/category/nation/2019/02/14/bumiputeraentrepreneurs- contribution-to-gdp-still-low-says-minister/

"2019 Budget: SMEs get major boost," New Straits Times, (2018). https://www.nst.com.my/business/2018/11/427731/2019-budget-smes-get-majorboost

"3,000 usahawan bergerak dilahirkan tahun ini," Utusan, (2017). http://www.utusan.com.my/berita/nasional/3-000-usahawan-bergerak-dilahirkan-tahun ini1.522903,.

"3,747 Rural Entrepreneurs Benefit from RM376m Funding” The sun daily, (2016). https://www.thesundaily.my/archive/2070695-YTARCH410220

Haji, A., \& Ghazali, M. N. A. (2012). Intellectual capital disclosure trends: Some Malaysian evidence. Journal of Intellectual Capital Disclosure, 13(3), 377-397.

Asmawiyah, A. (2018). Pengaruh Motivasi dan Kedisiplinan terhadap Kinerja Karyawan pada Restoran A\&W Mall Trans Studio Makassar. Jurnal Ilmiah Pena: Sains dan Ilmu Pendidikan, 10(1), 64-69. 
INTERNATIONAL JOURNAL OF ACADEMIC RESEARCH IN BUSINESS AND SOCIAL SCIENCES

Vol. 10, No. 10, 2020, E-ISSN: 2222-6990 @ 2020 HRMARS

Asmawiyah, M. M., Taba, M. I., \& Hamid, N. (2020). The Role Entrepreneur Competence as Mediation Human Capital on Business Performance. International Journal of Innovative Science and Research Technology, 5 (6), 812-819.

Felicio, J. A., Couto, E., \& Caiado, J. (2014). Human capital, social capital and organizational performance. Journal of Management Decision, 52(2), 350-364.

Human Capital Report: Rankings. (2016). Retrieved from World Economic Forum Web site: http://reports.weforum.org/human-capital-report-2016/rankings/

National Transformation Programme. (2015). National Transformation Programme Annual Report. Putrajaya: Department of Prime Minister.

Pfeffer, J., \& Salancik, G. R. (2003). The external control of organisations: A resource dependence perspective. Stanford University Press.

TalentCorp. (2016). Carving Malaysia's future of work. Retrieved from TalentCorp Web Site: https://www.talentcorp.com.my/about/about-us 